\title{
Marek SKIERKOWSKI*
}

\section{Ekoteologiczny charakter niedzieli}

Papież Jan Paweł II w liście apostolskim o świętowaniu niedzieli Dies Domini $(1998)^{1}$ napisal, że dzień Pański wiąże się ściśle "z samą istotą chrześcijańskiego misterium”2 i „stanowi samo centrum chrześcijańskiego życia"3. W niniejszym artykule, w świetle papieskiego listu, pragnę spojrzeć na niedzielę jako dzień zachwytu nad stworzeniem, aby w ten sposób ukazać ekologiczny wymiar religii chrześcijańskiej. Niedziela właśnie w sposób szczególny stanowi dzień zachwytu nad światem, który wyszedł z ręki Boga, i który stał się potem "nowym stworzeniem” (por. 2 Kor 5,17), po dokonaniu przez Chrystusa dzieła Odkupienia. „W doświadczeniu chrześcijańskim - zauważa Papież - niedziela jest przede wszystkim świętem paschalnym, całkowicie opromienionym przez blask chwały zmartwychwstałego Chrystusa. Jest świętowaniem "nowego stworzenia». Ale właśnie ten jej charakter, jeśli rozumiemy całą jego głębię, wskazuje na nierozerwalną więź niedzieli z tym, co Pismo Święte już na pierwszych stronicach mówi nam o Bożym zamyśle wyrażonym w stworzeniu świata"4.

\section{Zachwyt nad stworzeniem}

Papież przywołuje dwa fragmenty Nowego Testamentu (J 1,3 i Kol 1, 16) ukazujące Syna Bożego, przez którego wszystko się stało, wszystko zostało stworzone. W konsekwencji Jan Paweł II podkreśla, że chrystocentryzm spaja dwa wielkie wydarzenia w dziejach ludzkości: "stworzenie świata i zmartwychwstanie Chrystusa. Znakiem związanym z dziełem stworzenia byl szabat, a $z$ "nowym stworzeniem", zapoczątkowanym przez Chrystusowe powstanie z martwych - niedziela. „Trzeba zatem - konkluduje Papież - odczytać na nowo wspaniały opis stworzenia

\footnotetext{
Wydzial Teologiczny, UKSW Warszawa. Wydanie polskie: Wrocław 2000 (odtąd skrót: DD).

DD, 1.

DD, 7.

DD, 8 .
} 
i pogłębić teologię «szabatu», aby wejść na drogę wiodącą do pełnego zrozumienia niedzieli" ${ }^{5}$.

Biblijne opisy stworzenia świata (por. Rdz 1,1-2, 4a; 2,4b-25; Am 4,13; 5,8n; 9,6; Jr 10,12n; 14,21n; 31,35n; Ps 104; Hi 38-42; Syr 42,15-23; 43; Mdr 11,21-26; 2 Mch 7,20-29) nie są ani kosmologia, ani opowiadaniem historycznym, lecz refleksją o pochodzeniu świata od Boga ${ }^{6}$. Świat nie powstał sam z siebie, jest dziełem, czyli darem, Boga, wyrazem Jego potęgi i mądrości . „Na początku Bóg stworzył niebo i ziemię" (Rdz 1,1) - tymi słowami rozpoczyna się Biblia. „Poetycki styl narracji Księgi Rodzaju komentuje Jan Paweł II - dobrze wyraża zdumienie człowieka w obliczu ogromu stworzenia oraz płynące stąd uwielbienie dla Tego, który wszystkie rzeczy wyprowadził z nicości. Stronice te maja głęboką wymowę religijną - są hymnem na cześć Stwórcy wszechświata i ukazują Go jako jedynego Pana, przez co odpierają pojawiające się wciąż na nowo pokusy ubóstwienia samego świata, a zarazem są hymnem opiewającym dobroć rzeczywistości stworzonej, ukształtowanej przez wszechmocną i miłosierną dłoń Boga"8.

Dwa opisy stworzenia świata zawarte w Księdze Rodzaju (1,1-2, 4a oraz $2,4 \mathrm{~b}-3,24)$, należą do dwóch różnych tradycji odpowiednio: kapłańskiej (V w. przed Chr.) i jahwistycznej (X w. przed Chr.). Jak wskazuje S. Synowiec wprawdzie nie można obydwu tekstów zaliczyć do klasycznych hymnów, to jednak bez watpienia posiadają one formę artystyczną i należą do literatury pięknej. Autorzy tych tekstów wyrażają zachwyt nad dziełem stwórczym Boga. Zachwyt ten udziela się także czytelnikowi, ale istotne jest przede wszystkim pewne przesłanie religijne, które Biblia kieruje do czlowieka9. To przesłanie pierwszych stronic Księgi Rodzaju Papież streszcza w sposób następujący: „Wszechświat jest dziełem rąk Boga, nosi zatem znamię Jego dobroci. Jest piękny i godny podziwu, zasługuje na to, byśmy się nim cieszyli"10. „Bóg widział, że były dobre” (por. Rdz 1,10.12 itd.) - to wciąż powracający refren mówiący, że rzeczy tego świata są dobre: „świat jest dobry w takiej mierze, w jakiej pozostaje złączony ze swoim źródłem"11.

Wśród stworzeń, które otrzymywały od Boga istnienie, człowiek zajmuje wyjątkowe miejsce. Jest powołany do życia inaczej niż zwierzęta. Inny też jest cel jego istnienia. Tylko w narracji o stworzeniu człowieka

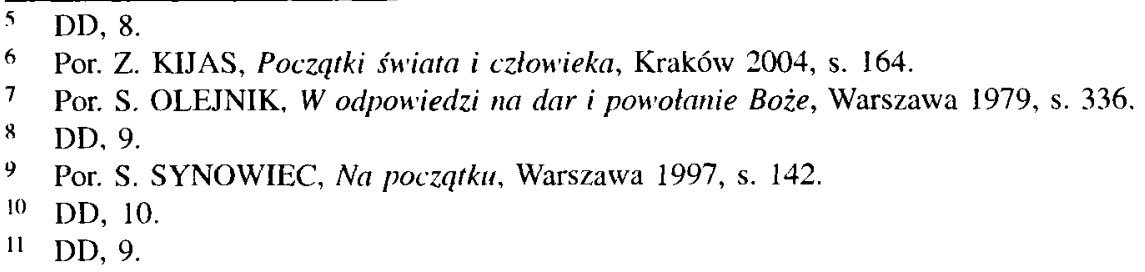


wskazuje się, że Bóg uroczyście zwraca się do samego siebie: „Uczyńmy człowieka na Nasz obraz, podobnego Nam" (Rdz 1,26). Następnie Bóg ożywił człowieka własnym tchnieniem: „Ulepił człowieka z prochu ziemi i tchnął w jego nozdrza tchnienie życia, wskutek czego stał się czlowiek istotą żywą" (Rdz 2,7). Żadne spośród pozostałych stworzeń nie zostało powołane do życia w podobny sposób. Aby zaistnial człowiek, nie wystarczyło ani słowo, ani nawet czyn Boży; potrzebne było specjalne Boże tchnienie $^{12}$. Jan Paweł II ukazując wielkość człowieka stworzonego na obraz i podobieństwo Boże zwraca uwagę na jeden tylko szczegół: człowiek, ,jest powołany nie tylko do tego, by mieszkać w świecie, ale by go "budować", stając się w ten sposób "współpracownikiem» Boga"13.

Proch ziemi, z którego został wyprowadzony człowiek, przywodził pobożnemu Izraelicie myśl o przemijaniu: „Prochem jesteś i w proch się obrócisz" (Rdz 3,9). Tym bardziej wielkiej rangi nabiera uczynienie człowieka współpracownikiem Boga, rządcą świata. „Człowiek [...] - czytamy w Gaudium et spes - stworzony na obraz Boga, otrzymal polecenie, aby poddając sobie ziemię ze wszystkim, co się na niej znajduje, panował nad światem $w$ sprawiedliwości i świętości oraz by uznając Boga za Stwórcę wszechrzeczy, odnosil do Niego siebie samego i całą rzeczywistość, tak aby mimo podporządkowania czlowiekowi wszystkich rzeczy, imię Boże było wysławiane po całej ziemi"14.

W ramach tego właśnie panowania nad światem należy rozumieć istotę odpoczynku od pracy. "Skoro "praca» Boga - stwierdza Jan Paweł II w liście apostolskim Dies Domini - opisana na pierwszych stronicach Księgi Rodzaju, jest przykładem dla człowieka, to jest nim również Boży «odpoczynek». "Odpoczął dnia siódmego po całym swym trudzie, jaki podjął» (Rdz 2,2)"15. Według deistycznego odczytania - zauważa A. Ganoczy - mogłoby się wydawać, że Bóg już przestał wpływać na dzieje świata; tymczasem Papież podejmuje interpretację propagowaną przez G. von Rada i wielu innych biblistów, według której Bóg ostatniego dnia zwraca się łaskawie ku całości swego dzieła ${ }^{16}$. „Odpoczynek Boga w siódmym dniu - wyjaśnia Papież - nie wskazuje zatem na Boga, który przestał "pracować», ale podkreśla doskonałość wykonanej pracy i ma raczej oznaczać, że zatrzymał się On przed dziełem swoich rąk, kierując ku niemu spojrzenie pełne radości i zadowolenia, gdyż było «bardzo dobre» (Rdz 1,31). Jest to więc spojrzenie «kontemplacyjne», które nie

12 Por. K. ROMANIUK, Krótki zary's historii zbawienia, Warszawa 1987, s. 25.

13 DD, 10.

14 Sobór Watykański II, Gaudium et spes, 34 (wydanie polskie: Sobór Watykański II, Konstytucje, dekrety; deklaracje, Poznań 2002).

15 DD, 11.

16 Por. A. GANOCZY, Nauka o stworzeniu, Kraków 1999, s. 40. 
zwraca się ku następnym dziełom, lecz pozwala raczej zachwycić się pięknem tego, co już zostało dokonane. Kieruje się ono ku wszystkim rzeczom, ale w szczególny sposób ku człowiekowi, który jest zwieńczeniem stwórczego dzieła"17.

Kontemplacyjne spojrzenie Boga siódmego dnia jest spojrzeniem oblubieńczym. "W tym spojrzeniu - kontynuuje Jan Paweł II - można już w pewien sposób dostrzec «oblubieńczy» charakter relacji, jaką Bóg pragnie nawiązać ze stworzeniem uczynionym na Jego obraz, powołując je do zawarcia z Nim przymierza miłości"18. W tej perspektywie szabat to dzień objawienia się Oblubieńca wobec swojej Oblubienicy, a więc Boga wobec człowieka, będącego szczytem stworzenia. Idea Boga jako Oblubieńca, a Izraela jako Oblubienicy, została najpełniej ukazana w Księdze Ozeasza: „Dlatego - mówi Bóg - chcę ją przynęcić, na pustynię ją wyprowadzić i tam mówić do jej serca. Oddam jej znowu winnice, dolinę Akor uczynię bramą nadziei. I odpowie mi tam jak za dni swej młodości, gdy wychodziła z ziemi egipskiej" (Oz 2,16-17). Ozeasz jako pierwszy z proroków Izraela przedstawił miłość Boga do swego ludu w kategorii związku małżeńskiego, któremu towarzyszą najgorętsze nawet uczucia ${ }^{19}$. W tej perspektywie oczekiwany dzień zbawienia jawi się jako dzień zaślubin: „I poślubię cię sobie znowu na wieki, poślubię przez sprawiedliwość i prawo, przez miłość i miłosierdzie. Poślubię cię sobie przez wierność, a poznasz Pana" (Oz 2,21-22).

"Bóg pobłogosławił ów siódmy dzień i uczynił go świętym" (Rdz 2,3 ). Głębia szabatu sprawiła, że nie został on umieszczony wśród zwykłych przepisów kultowych, lecz stał się „częścią Dekalogu - «dziesięciu słów» stanowiących filary życia moralnego, zaszczepionego w sercu każdego człowieka. Rozpatrując to przykazanie jako element fundamentalnych struktur etyki, Izrael, a później Kościół ukazują, że nie uważają go za jeden $z$ wielu przepisów dyscyplinarnych, regulujących wspólnotową praktykę religijna, ale za istotny i nieodzowny znak relacji z Bogiem"20. "Szabat - wyjaśnia J. Schreiner, wielki biblista Starego Testamentu - jest czasem wydzielonym, wyjętym $\mathrm{z}$ nieustannego biegu zajęć i pogoni za zyskiem (Am 8,5). Sam Jahwe "uświęcił» ów dzień, wyłączył go ze świeckiej aktywności. Jeżeli jest przestrzegany i zachowywany, to człowiek uiszcza niejako dziesięcinę $z$ podarowanego przez Boga i odmierzonego czasu i za ten czas. Jako czas wolny od codziennych obowiązków i czynności, daje szabat okazję do świętowania. Ponieważ zarządził go Jahwe,

\footnotetext{
DD, 11 .

DD, 11.

19 Por. T. BRZEGOWY, Święty Bóg i jego grzeszna oblubienica Izrael, w: tenże i in., Wielki świat starotestamentalnych proroków', cz. I, Warszawa 2001, s. 76.

DD, 13.
} 
wzrok zwraca się ku Niemu, Stwórcy (Wj 20,11)"21. W Starym Testamencie obowiązek szabatu związany jest ze słowem „pamiętaj". W Wj 20,8.11 czytamy: „Pamiętaj o dniu szabatu, aby go uświęcić. [...] W sześciu dniach bowiem uczynił Pan niebo, ziemię, morze oraz wszystko, co jest $w$ nich, w siódmym zaś dniu odpoczął. Dlatego pobłogosławił Pan dzień szabatu i uznał go za święty". Szabat ma zatem charakter prawdziwie sakralny. "«Odpoczynek » człowieka - pisze Jan Paweł II - w dniu Pańskim zyskuje właściwy sens $w$ takiej mierze, $w$ jakiej żywa jest ta «pamięć», przeniknięta wdzięcznością i uwielbieniem Boga. Znając ten sens człowiek może wejść głęboko w wymiar «odpoczynku» Boga i mieć w nim udzial, a dzięki temu przeżyć to samo radosne wzruszenie, jakiego zaznał Stwórca, gdy dokończywszy dzieła stworzenia zobaczył, że wszystko, co uczynił, «było bardzo dobre»" 22 .

W sposób niezwykle sugestywny - poetycki i mistyczny - Papież wyraził to spojrzenie Boga na dzieła stworzone w Tryptyku Rzymskim:

„Ten, który stwarzał, widział - widział, «że było dobre», widział widzeniem różnym od naszego,

On - pierwszy Widzący -

Widzial, odnajdywał we wszystkim jakiś ślad swej Istoty, swej pełni Widział: Omnia nuda et aperta sunt ante oculis Eius -

Nagie i przejrzyste -

Prawdziwe, dobre i piękne -

Widział widzeniem jakże innym niż nasze"23.

Niedziela, przejmując treść szabatu, stanowi dla człowieka sposobność do przeżycia zachwytu nad stworzeniem - na wzór samego Boga. Chodzi więc o to "spojrzenie inne", kontemplacyjne, oblubieńcze, a nie egoistyczne, nasycone pragnieniem posiadania, eksploatacji czy panowania. Jak napisał $Z$. Kijas, „Biblia uczy, że osoba wierząca powinna zbliżać się do przyrody nie jak do czegoś dzikiego, co trzeba ujarzmić, lecz jak do rzeczywistości przedstawiającej zdumiewający wyraz Boskiej mądrości. Chrześcijańska postawa wobec przyrody sprowadza się zatem do troski o dzieło Boże, aby nie ulegało degradacji i zniszczeniu, ale aby rozwijało się, osiągając coraz większą doskonałość"24.

T. SCHREINER, Teologia Starego Testamentu, Warszawa 1999, s. 357.

DD, 17

2.3 JAN PAWEE II, Tryptyk Rzymski, Kraków 2003, s. 15-16.

24. Z. KIJAS, Poczqtki świata i człow'ieka, s. 170. 


\section{Zachwyt nad ,nowym stworzeniem”}

Pierwsi chrześcijanie, świadomi, że największe dzieło Boże miało miejsce w zmartwychwstaniu Chrystusa, zaczęli świętować pierwszy dzień po szabacie. „Paschalne misterium Chrystusa - wyjaśnia Jan Paweł II - jest bowiem pełnym objawieniem misterium początków, zwieńczeniem historii zbawienia i zapowiedzią eschatologicznego końca świata. To, czego Bóg dokonał w stworzeniu i co uczynił dla swego ludu wyprowadzając go $z$ Egiptu, dopełniło się w śmierci i zmartwychwstaniu Chrystusa, choć ostatecznie wyrazi się dopiero $w$ momencie paruzji, kiedy On przyjdzie $w$ chwale"25. Radość zatem, która towarzyszyła Bogu przyglądającemu się swemu stworzeniu wydobytemu z nicości, staje się radością uczniów spotykających Zmartwychwstałego (J 20,19-23). „W świetle tej tajemnicy kończy Papież - sens starotestamentowego nakazu świętowania dnia Pańskiego zostaje odzyskany, ubogacony i w pełni ukazany w chwale, która jaśnieje na obliczu Chrystusa zmartwychwstałego (por. 2 Kor 4,6). Od «szabatu" przechodzimy tu do "pierwszego dnia po szabacie», od siódmego dnia do "dnia pierwszego»: dies Domini staje się dies Christi"26.

Zmartwychwstanie Chrystusa stanowi bez wątpienia szczytowy moment historii zbawienia. „A jeśli Chrystus nie zmartwychwstał - pisał św. Paweł - daremne jest nasze nauczanie, próżna jest także wasza wiara" (1 Kor 15,14). W spuściźnie literackiej św. Pawła, powstałej jeszcze przed Ewangeliami, odnajdujemy przebogate źródło najstarszych tekstów o zmartwychwstaniu Jezusa. Można w nich wykryć trzy zasadnicze schematy teologiczno-terminologiczne: schemat wskrzeszenia $\mathrm{z}$ martwych, schemat wywyższenia i schemat powrotu do życia. Pierwszy schemat, horyzontalny, opiera się na następstwie czasowym to, co było przedtem to, co byto potem: Chrystus umarł i zmartwychwstał trzeciego dnia (np. 1 Kor 15,4). Drugi z kolei, wertykalny, bazuje na antytezie poniżenie - wywoyższenie: Chrystus uniżył się aż do śmierci krzyżowej, ale został wywyższony w chwale (np. Flp 2,6-11). O ile w pierwszym schemacie podkreśla się identyfikację cielesną Zmartwychwstałego $\mathrm{z}$ Ukrzyżowanym, o tyle $\mathrm{w}$ drugim akcentuje się przemianę, dzięki której Ukrzyżowany przez swoje zmartwychwstanie stał się Panem wszechświata. Trzeci wreszcie schemat, najmniej adekwatny, gdyż redukuje on zmartwychwstanie do zwykłego wskrzeszenia, odwołuje się do starotestamentalnej koncepcji Boga, spraziającego, że człowiek umiera i odzyskuje życie: Chrystus umarł i powrócił do życia (np. Rz 14,9). Schemat ten musi być brany pod uwagę w łączności z dwoma pozostałymi. Inna sprawa, że i te dwa pozostałe schematy czasami także łączą się ze sobą, tworząc schemat mieszany (np. Ef 1,20-

25 DD, 18.

26 DD, 18. 
22). Schematy te wskazują zatem, że zmartwychwstanie polega na dogłębnej transformacji: "tego, co zniszczalne" w "to, co niezniszczalne" (por. 1 Kor 15,42). „W wydarzeniu zmartwychwstania Jezusa - pisze T. Dola - objawia się Bóg, który jest pełnią życia"27.

Niełatwo było ewangelistom opisać rzeczywistość zmartwychwstania. Efekty ich wysiłku streszcza niejako Katechizm Kościoła Katolickiego: „Jezus zmartwychwstały nawiązuje z uczniami bezpośredni kontakt przez dotyk i wspólny posiłek. Zaprasza ich $w$ ten sposób do uznania, że nie jest duchem, ale przede wszystkim do stwierdzenia, że zmartwychwstałe ciało, w którym się im ukazuje, jest tym samym ciałem, które zostało umęczone i ukrzyżowane, ponieważ nosi On jeszcze ślady swojej męki. To autentyczne i rzeczywiste ciało posiada jednak równocześnie nowe właściwości ciała uwielbionego: nie sytuuje się ono już w czasie i przestrzeni, ale może uobecnić się na swój sposób, gdzie i kiedy chce, ponieważ Jego człowieczeństwo nie może już być związane z ziemią i należy wyłącznie do Boskiego panowania Ojca. [...] W swoim zmartwychwstałym ciele Jezus przechodzi ze stanu śmierci do innego życia poza czasem i przestrzenią. Ciało Jezusa zostaje w Zmartwychwstaniu napełnione mocą Ducha Świętego; uczestniczy On w Boskim życiu w stanie chwały, tak że św. Paweł może powiedzieć o Chrystusie, że jest "człowiekiem niebieskim»"28.

Tak rozumiane zmartwychwstanie Chrystusa ma głęboki sens historiozbawczy. „Historiozbawcze znaczenie zmartwychwstania Chrystusa wyjaśnia kard. Ch. Schönborn - polega głównie na tym, że nie zmartwychwstał On sam. Jego zmartwychwstanie jest początkiem, przyczyną, a także w pewnej mierze już realizacją powszechnego zmartwychwstania umarłych. Powszechne zmartwychwstanie przy końcu czasów nie jest bowiem jakimś innym, odizolowanym wydarzeniem, ale przynależy nierozłącznie do zmartwychwstania Jezusa. Ostatni (ostateczny) dzień już nadszedł. Śmierć Jezusa jest «dniem i godziną» nadejścia królewskiego panowania Boga. Królestwo Boże już się rozpoczęło, a wraz z nim kres czasu. Wraz z porankiem wielkanocnym zaczęło się nowe stworzenie"29.

Jednakże - podkreśla Jan Paweł II - wedle zgodnego świadectwa Ewangelii, zmartwychwstanie Jezusa Chrystusa nastąpiło nie w szabat,

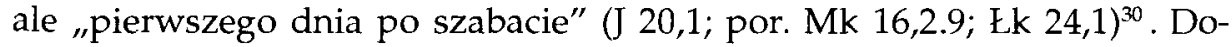
kładnie mówiąc, tego właśnie dnia odkryto pusty grób i miały miejsce pierwsze chrystofanie. Relacja Marka: "Po upływie szabatu [...], wczesnym rankiem $w$ pierwszy dzień tygodnia, [...] gdy słońce wzeszło" (16,1-2); relacja Mateusza: „Po upływie szabatu, o świcie pierwszego dnia

\footnotetext{
27 T. DOLA, Teologia misteriów życia Jezusa, Opole 2002, s. 256.

28 KKK, 645-646.

29 Ch. SCHÖNBORN, Bóg zestat Syna Swego. Chrystologia, Poznań 2002, s. 356.

3) Por. DD, 20
} 
tygodnia $(28,1)$; relacja Łukasza: „W pierwszy dzień tygodnia, [...] skoro świt” (24,1); relacja Jana: „Pierwszego dnia tygodnia po szabacie, wczesnym rankiem, gdy jeszcze było ciemno [...]" $(20,1)$. Stopniowo zaczęto więc odróżniać niedzielę od szabatu, święta żydowskiego, mimo że z początku współistniał zwyczaj zarówno zachowywania szabatu, jak i świętowania niedzieli. „Szabat - pisze J. Decyk - zamykał tydzień, niedziela rozpoczynała tydzień czasów nowych przez wspomnienie Zmartwychwstania i ukazania się Chrystusa zmartwychwstałego w duchu oczekiwania na Jego ostateczny powrót. Niedziela oznacza spełnienie się obietnic, których szabat był tylko figura" ${ }^{\prime 3}$. Św. Ignacy z Antiochii mógł na początku II w. napisać o chrześcijanach, że „przyszli [oni] do nowej nadziei i nie zachowują już szabatu, ale obchodzą dzień Pański, dzień, w którym nasze życie powstało $z$ martwych przez Chrystusa i Jego śmierć" ${ }^{\prime \prime 2}$. Zdaniem Jana Pawła II, różnica między niedzielą i szabatem stawała się coraz wyraźniejsza, chociaż $w$ historii dochodziło jeszcze do obchodzenia i szabatu, i niedzieli - używając sformułowania św. Grzegorza z Nyssy jako "dwóch bratnich dni" ${ }^{33}$.

Związek niedzieli z szabatem pozwolił teologii odnaleźć nić łączącą zmartwychwstanie ze stworzeniem. „Chrześcijańska refleksja - wskazuje Jan Paweł II - spontanicznie bowiem powiązała zmartwychwstanie, które nastąpiło «w pierwszym dniu tygodnia», z pierwszym dniem owego kosmicznego tygodnia (por. Rdz 1,1-2.4), w którym według opisu Księgi Rodzaju dokonały się kolejne etapy dzieła stworzenia, a mianowicie $\mathrm{z}$ dniem stworzenia światła (por. 1,3-5). To powiązanie pozwalało rozumieć zmartwychwstanie jako początek nowego stworzenia, którego pierwociną był uwielbiony Chrystus - «pierworodny wobec każdego stworzenia» (por. Kol 1,15) i "pierworodny spośród umarłych» (Kol 1,18)"34.

Św. Justyn, św. Bazyli i Orygenes wskazali jeszcze inną interpretację niedzieli, mianowicie nazywając ją "dniem ósmym". Chodziło w tym sformułowaniu o przedstawienie niedzieli jako dnia zajmującego w cyklu tygodniowym pozycję wyjątkową i transcendentną - dnia trwającego bez końca, nie znającego zmierzchu ani świtu. $W$ tej interpretacji - napisał $\mathrm{Pa}$ pież - "niedziela jest nieustannym zwiastowaniem życia wiecznego, które podtrzymuje nadzieję chrześcijan i dodaje im sił w drodze ${ }^{\prime 35}$.

Niedziela stanowi nie tylko pamiątkę zmartwychwstania, ale przede wszystkim „świętowanie żywej obecności Zmartwychwstalego pośród

31 J. DECYK, Niedziela - Dzień Pana i Chrystusa, w: „Niedziela". VI Tydzień Spoteczny 69.V. 1999 r., Warszawa 1999, s. 49.

32 Św. IGNACY Z ANTIOCHII, List do Magnezjan, 9,1 (wydanie polskie: Ojcowie Apostolscy, pod red. W. Myszora, Warszawa 1990).

33 DD, 23

34 DD, 24.

35 DD, 25. 
wierzących"36. Chrześcijanin w sposób szczególny doświadcza obecności Chrystusa zmartwychwstałego podczas niedzielnej Eucharystii. Jak naucza Papież w encyklice Ecclesia de Eucharistia, "Ofiara eucharystyczna uobecnia nie tylko tajemnicę męki i śmierci Zbawiciela, lecz także tajemnicę zmartwychwstania, w której ofiara znajduje swoje wypełnienie" ${ }^{37}$. "Zaiste. Eucharystia jest bramą nieba, która otwiera się na ziemi. Jest promieniem chwały niebieskiego Jeruzalem, który przenika cienie naszej historii i rzuca światto na drogi naszego życia"38. "Wszyscy uczestniczący $w$ Eucharystii podejmuja zadanie przemiany życia, aby w pewnym sensie stało się ono całe «eucharystyczne». Właśnie ten owoc polepszenia egzystencji i zaangażowanie na rzecz przemiany świata zgodnie $z$ Ewangelią, wyrażają aspekt eschatologiczny Ofiary eucharystycznej i całego życia chrześcijańskiego" ${ }^{\prime 39}$.

Nietrudno zatem zauważyć, że człowiek, celem odkrycia pełnego sensu niedzieli, musi przeżyć prawdziwy zachwyt odkupionym światem; zachwyt owocujący prawdziwą radością życia, harmonią wewnętrzną i wytchnieniem dającym zapał do dalszej pracy. „Niedziela - stwierdza Jan Paweł II - rozumiana jako dzień zmartwychwstałego Pana, w którym świętuje się Boże dzieło stworzenia i dzieło «nowego stworzenia», jest w szczególny sposób dniem radości, więcej - dniem sprzyjającym ksztaltowaniu w sobie postawy radości przez odkrywanie jej prawdziwych cech i głębokich korzeni" 40 . Tak rozumiana radość nie jest przelotnym doznaniem przyjemności, lecz trwałym usposobieniem ducha, czerpiącym moc od samego Boga. „Niestety - ubolewa Jan Paweł II - gdy niedziela zatraca pierwotny sens i staje się jedynie "zakończeniem tygodnia", zdarza się czasem, że horyzont człowieka stał się tak ciasny, że nie pozwala mu dojrzeć «nieba». Nawet odświętnie ubrany nie potrafi już «świętować»" ${ }^{\prime \prime 1}$.

\section{Wnioski}

Podsumowując, należy podkreślić, że niedziela $z$ samej swej istoty posiada zarówno wyraźny rys ekologiczny, jak i rys teologiczny. $Z$ tej racji, że jest ona dniem przerwania pracy, jawi się jako czas zachwytu nad przyrodą, uwolnienia natury od wpływu techniki, kontemplacji świata. Jednakże, rozpatrywanie niedzieli tylko w kategoriach ekologicznych -

36 DD, 31 .

37 JAN PAWEŁ II, Encyklika Ecclesia de Eucharistia, 14 (wydanie polskie: Poznań 2003).

38 Tamze, 19.

39 Tamże, 20.

4) DD, 57. Szerzej na temat radości życia zob. cały numer „Communio” 6/2004.

41 DD, 4. 
bez odniesienia do Objawienia - ukazywałoby niedzielę jedynie jako szkic pewnego arcydzieła. Teologia nadaje niedzieli wyższe, nadprzyrodzone motywy. Zachwyt nad światem staje się zachwytem nad Stwórcą. Zachwyt $\mathrm{z}$ kolei nad dziełem stwórczym Boga prowadzi do zachwytu nad "nowym stworzeniem", które Chrystusa zapoczątkował mocą swego zmartwychwstania i które osiągnie pełnię w wieczności. W Eucharystii chrześcijanin odnajduje Chrystusa zmartwychwstałego i doświadcza smaku tego "nowego stworzenia". W konsekwencji, ludzka troska o środowisko naturalne staje się odpowiedzialnością człowieka przed Bogiem Stwórcą i Bogiem Odkupicielem, aby udoskonalać świat w duchu Ewangelii i zaznać $z$ tego powodu najprawdziwszej radości. $W$ tej perspektywie $\mathrm{w}$ programie świętowania niedzieli, nie powinno zabraknąć zarówno fascynującego spotkania $z$ Chrystusem zmartwychwstałym na Eucharystii, jak i pełnego zachwytu przebywania na łonie natury. 